Journal of Law \& Social Studies (JLSS)

Volume 3, Issue 2, pp 187-201

www.advancelrf.org

\title{
Globalization's Effect on Environmental Degradation in Regional Cooperation
}

\author{
Khaula Walayat \\ NCBA\&E. \\ Email: Khaulawalayat@gmail.com \\ Dr. Mehmood Khalid Qamar \\ Vice Rector \\ NCBA \& E, Lahore. \\ Email: mahmoodqamar@ncbae.edu.pk
}

\begin{abstract}
This study sctrutinize the impact of defacto and dejure GLOB (as in explained in KOF GLOB index 2018) on Environmental degradation in EAGLE, BRICKS, European Unions \& NEXT11 countries. The defacto GLOB indicate the estimate of GLOB include variables that represent flows and activities, de jure estimate includes variables that shows policies that represents, enable flows and activities. Whereas the environmental GLOB is measured by CO2 Emission. The results show that dejure economic and social GLOB has significant impact on environmental degradation in EAGLE, BRICKS, European Union \& NEXT11 countries which indicates that the favorable trade \& financial GLOB policies in these countries enabled more economic GLOB led to more industrialization which deteriorates the environment in these countries. Yet political defacto \& dejure GLOB has no significant impact on countries within these regional Cooperation's.
\end{abstract}

Keywords: Regional Coperations, European Union, Defacto, Dejure, GLOB, CO2 (Carbon dioxide emission), EKU, GLOB (GLOB)

\section{Introduction}

GLOB is the network of trade. Social and political contacts among countries. It is the ease of exchanging and producing goods and services after the ban on trade barriers by WTO. In recent era where world is a global village. GLOB facilitates the transfer of technology and growth from less developed countries from most developed countries. Because of this the GLOB's participation in deciding environmental degradation is important, and it increases in investment and technical growth in a country. On the other hand, the increased production throughout the world needs more energy usage; which proves that the degradation environment is mostly by this increased usage of energy. In this study we have used $\mathrm{CO} 2$ emission to measure the amount of environmental degradation.

Globalization made ease of free trade and liberalization enabled countries to form regional cooperation like NAFTA, European Union, BRICS, NEXT11, EAGLE countries, ASIAN etc. These collaborations started a new discussion in research; Is environmental degradation increased by this new form of GLOB? Which induced us the idea to do this research. The widespread impression is that the increase in GLOB pressure is one of the most reasons behind worldwide natural changes. GLOB energizes improvement without a question; however, it makes negative externalities through natural debasement and biological defilement. Amid final few decades, natural impacts and exchange liberalization comes about due to GLOB process is one of the elemental issues in worldwide environmental change, So the GLOB impact is one of the fundamental components around the globe. GLOB is imperative due to improvement, great administration, mechanical up degree, devout and ethnic resistance. In spite of the fact that, GLOB opened the doors of free trade and liberalization, it created the challenges like imbalance, devout and ethnic pressures among nations.

Generally, the manufacturing of goods and services increase the opportunity cost of worsening of environmental quality and consumption of energy resources. Profoundly globalized country allots greater weights to natural 
framework, which be negative from a supportability point of view. In this way, the foremost globalized nations are not truly the foremost feasible countries. In any case, exceedingly globalized regions do not truly recommend positive outcomes. Lately the GLOB and its results for the environment have assembled tremendous thought with respect to the warmed discourse over the assumed Contamination Sanctuary Theory (PHH). Past examinations of this subject within the financial aspect's literature have experienced two central goals with regard to the component of GLOB, approximately each one of the examinations show up as either FDI or exchange rate and estimations of GLOB other than financial GLOB.

There are a few financial components of GLOB like request, generation, back, exchange, venture and competition. this considers centers on the effect of GLOB on natural debasement in territorial enterprises as per categorized by World Bank, it considers four distinctive territorial participation like Rising and growth-leading economies (Hawks,2020), Another 11, BRICS (Brazil, Russia, India and China) and European Union. This subject will propose arrangement producers to take the GLOB into the account. The foremost important thousand years advancement objectives are to decrease environment debasement and to extend the Worldwide organization by GLOB Economical sustainable development goals. So, the present study tries to contribute in the literature by investigating the effects of GLOB on environmental degradation as well as presence of the inverted Kuznet's curve relationship between GLOB and Carbon dioxide gas emission. $\mathrm{CO} 2$ gas emission is used as a proxy of deterioration of environmental for this regional cooperation. GLOB index used in this research is composed of four subcomponents and those components are economic, social, political. GLOB index is constructed by these three important components of GLOB.

The current study is organized in four sections like review of literature, methodology, results, discussion and conclusion.

\section{Literature Review}

This section consists of theoretical, conceptual, and empirical analyses regarding the nexus between energy-growthinduced emissions.

Environmental degradation is a process through which the natural environment is compromised in some way, reducing biological diversity and the general health of the environment. This process can be entirely natural in origin, or it can be accelerated or caused by human activities whereas the globalization is the network of trade, social and political contacts among countries. It is the ease of exchanging and producing goods and services after the ban on trade barriers by WTO.

The most concern of researchers in this subject is the effect of GLOB on economy and society, especially Environment. It is contended that integration into the worldwide economy advances financial development, which in turn makes a difference to fathom issues of destitution, inequality, and empirics propose a significant diminishment in poverty amid GLOB, particularly within the case of India and China.

(Phong, 2020) depicted that in later a long time, the challenging concern of declining worldwide natural quality has unequivocally showed, which is obviously outlined by increase in $\mathrm{CO} 2$ (Carbon Dioxide - one of the major ingredients of the nursery impact) within the climate. But financial analysts as well as researchers strived to investigate and examine the factors of $\mathrm{CO} 2$ emanations like vitality utilization, financial development, budgetary advancement and urbanization by different national and worldwide investigates in arrange to back maintainable improvement arrangements, the comes about with respect to the relationship between the previously mentioned components and natural harm stay questionable (Omri, 2013; Strict, 2004; Dinda, 2004).

The final a few decades seen the solid advancement of financial exercises which tensed the situation for their impacts on the environment at national and worldwide levels. The interface among financial development and natural quality has drawn impressive considerations since Natural Kuznets Bend (EKC) theory which accept that financial development emphatically impacts $\mathrm{CO} 2$ emanations within the starting arrange, but the impact is negative within the consequent arrange after the $\mathrm{CO} 2$ outflows comes to the greatest level associated with a certain sum of wage per capita.

(Balsalobre-Lorente, et al. 2020); proposes that these issues are caused due to air nursery gas (GHG) emanations.

Previous researches show that, around the world, the carbon dioxide emanations in 2014 was almost $42 \%$ more than in 1990. This implies that, around the world, the absorption of carbon dioxide in the air has been extended at a 
significant level (Aung et al. 2017). With quick financial development and improvement, the concentration of carbon dioxide emanations has been significantly expanding amid decades.

There are diverse conclusions with respect to the impact of GLOB on the environment. Grossman (1991) and Shahbaz et al. (2017) examined that GLOB incorporates a positive effect on natural debasement. In addition, numerous analysts have inspected that the variables of financial GLOB have a critical effect on natural corruption, for occasion (Suki.N.M. et al;2020). In differentiate,

In many other studies they focused on measuring the relationship among vitality utilization, GLOB, financial development, monetary advancement, and carbon dioxide emanations. In any case, these considers are constrained in number. In this setting, Shahbaz et al. (2017) explored the effect of GLOB on carbon dioxide Environ Sci Pollut Res emanations by counting vitality utilization and financial development in Japan, crossing the period of 1970-2014 utilizing NARDL show and inspected that vitality utilization, GLOB, and financial development increment carbon dioxide emanations. In any case, Shahbaz et al. (2017) found that GLOB list and the sub- indices of GLOB diminish carbon dioxide discharges with EKC, in China from 1970 to 2012. Comparative comes about were moreover found by Shahbaz et al. (2013c) over the period 1970-2010 in Turkey and inspected that GLOB diminishes carbon emanations within the nearness of EKC.

(Haseen et al,2018) inspected the effect of vitality utilization, budgetary improvement, GLOB, financial development, and expansion on different economies. They proved that GLOB diminishes carbon dioxide outflows within the presence of the EKC theory for BRICS nations.

\section{Model Specification and Data Sources}

As this study focuses on the impact of GLOB on environmental degradation in regional corporations as per categorized by World Bank, it considers four different regional cooperation like Emerging and growth-leading economies (EAGLEs), NEXT 11, BRICS (Brazil, Russia, India and China) and European Union. This cooperation is selected because of convenient availability of data. For the measurement of GLOB, it uses the improvised version of KOF GLOB index introduced by Gy). This index is comprised of social, economic and political GLOB, each having defacto and dejure dimensions. Economic GLOB is subdivided into trade and financial GLOB. Social GLOB is subdivided into interpersonal, information and cultural GLOB. Figge and Martens (2014) propose two additional dimensions in the Maastricht GLOB Index, which are technological and ecological GLOB. While technological GLOB includes measures of communication technology that overlap with the social dimension of the KOF GLOB Index, the ecological dimension is a distinct feature of the Maastricht GLOB Index.

\section{Methodology}

The Globalization is multicounty phenomenon and this study focusses on the nexus of this factor with inequality and environmental degradation. So, in the present scenario, the cross-sectional regression is commonly used to capture the relationship among above mentioned variables at one point of time. But in order to consider the impact of time series data along with cross sections, panel data techniques are more appropriate as they utilize both cross sectional and time data for the analysis. These techniques enhance the strength and size of the data sets, leading to reorganization of the analysis (Hsiao 1986). Moreover, the panel data methods have more leaverage for more hetrogeniety, variablility, efficiency and degree of freedom so, the models which are analyszed by these methods, have lesser restrictions (Baltagi, 2001).

So, the present study has utilized the panel data for the analysis and hence, the functional panel data models which have analyzed are three basic model. First is for economic GLOB, second is for political GLOB and third is for social GLOB as follows:

$$
\begin{aligned}
& \mathrm{CO} 2=\mathrm{a} 1+\beta 2 \mathrm{i} \text { DfEGt }+\beta 3 \mathrm{iDjEG} \text { it }+\beta 4 \mathrm{iPPPit}+\beta 5 \mathrm{i} \mathrm{HCit}+\mu \mathrm{it} \\
& \mathrm{CO} 2=\mathrm{a} 1+\beta 2 \mathrm{i} \mathrm{DfPGt}+\beta 3 \mathrm{iDjPG} \text { it }+\beta 4 \mathrm{iPPit}+\beta 5 \mathrm{i} \mathrm{HCit}+\mu \mathrm{it} 3.2 \\
& \mathrm{CO} 2=\mathrm{a} 1+\beta 2 \mathrm{i} \mathrm{DfSGt}+\beta 3 \mathrm{iDjSG} \text { it }+\beta 4 \mathrm{iPP} \mathrm{Pt}+\beta 5 \mathrm{i} \mathrm{HCit}+\mu \mathrm{it} 3.3
\end{aligned}
$$

Where

$\mathrm{CO} 2=\mathrm{CO} 2$ emissions per metric; 
DfEG and DJEG = defacto and dejure KOF economic GLOB index; DfPG and DJPG = defacto and dejure KOF political GLOB index; DfSG and DJSG = defacto and dejure KOF social GLOB index; PPP= purchasing power parity

$\mathrm{HC}=$ human capital index and $\mu=$ error term

it $=$ panel data $(\mathrm{i}$ for cross section $\mathrm{t}$ for time series $)$

For the analysis of panel data models, three basic techniques are pooled ordinary least square (OLS), fixed effects and random effects. The pooled OLS model assumes homogeneity among cross sections. But if the specification of model requires the heterogeneity, fixed and random effects methods are applied. The fixed effects model assumes the heterogeneity among cross sections and time with the help of varying intercept whereas random effects model allows for random distribution in error variances. This study applies both fixed and random effects methods on different models. The decision of application of either in a specific model is done on the rejection and acceptance of null hypothesis in Hausman test (Hausman, 1978). To apply fixed effect model, we first have to check the properties of ordinary least square tests.

Then the same tests were applied on other panels to keep the findings comparable. The results of Hausman tests for BRICS are given below.

Table 4.1: Hausman Test for Model Specification (BRICS)

\begin{tabular}{|l|l|l|l|l|}
\hline Hausman & Coefficient & Coefficient & Difference & S. E \\
(b) RE & $(\mathrm{B}) \mathrm{FE}$ & \\
\hline KOFECGLDF & -.1023162 & -.0904871 & .0118291 & .0209536 \\
\hline KOFECGLDJ & -.0658977 & -.024355 & .0415427 & .0163645 \\
\hline KOFSOGLDF & .6783019 & .2215223 & .4567796 & .0168129 \\
\hline KOFSOGLDF & -.1483989 & .0036494 & .1520483 & .004974 \\
\hline KOFPOGLDF & .0804298 & .0372869 & .0431429 & .0189985 \\
\hline KOFPOGLDF & -.1200769 & -.0211517 & .0989252 & .0096298 \\
\hline PPP & -.0003592 & -.0000734 & 0002858 & .0000374 \\
\hline AGEDEPEND & .036005 & .0195868 & .0164182 & .000000 \\
\hline CHI-SQ & 99.79 & PROBABILITY & 0.0000 & \\
\hline
\end{tabular}

In the table 4.1, the results show that the null hypothesis of no difference between fixed effects and random effects model is rejected against the alternative hypothesis stating that the fixed effects model is preferable. So, based on these preliminary estimates fixed effects model with cross-sectional weights is finalized for our panel data analysis. Then the same tests were applied on NEXT11 panels to keep the findings comparable. The results of Hausman tests are given below. 
Table 4.2: Hausman Test for Model Specification (NEXT11)

\begin{tabular}{|l|l|l|l|l|}
\hline Hausman & Coefficient & Coefficient & Difference & S. E \\
& (b) RE & (B) FE & \\
\hline KOFECGLDF & -.091445 & -.1427014 & .0512564 & - \\
\hline KOFECGLDJ & .2111244 & .2860203 & -.0748959 & - \\
\hline KOFSOGLDF & -.1057044 & .4075133 & -.5132177 & - \\
\hline KOFSOGLDJ & .0966417 & -.5584333 & .655075 & .0209536 \\
\hline KOFPOGLDF & .0310343 & .6779922 & -.6469579 & .0163645 \\
\hline KOFPOGLDJ & -.076308 & 1.341528 & -1.417836 & .0168129 \\
\hline PPP & -.5019015 & -1.656419 & 1.154518 & .004974 \\
\hline AGEDEPEND & -1.278831 & -1.987943 & .7091115 & 2170737 \\
\hline HCI & .9959583 & 2.495852 & -1.499894 & - \\
\hline CHI-SQ & -1857.48 & Probability & 0.000 & \\
\hline
\end{tabular}

So, based on Hausman model specification test, fixed effects are more reliable for model estimation of NEXT11 and Hausman test for EAGLE countries is given below.

Table 4.3: Hausman Test for Model Specification (EAGLE)

\begin{tabular}{|l|l|l|l|l|}
\hline HAUSMAN FE & COEFFICIENTS & COEFFICIENTS & DIFFERENCE & S. E \\
& $(\mathrm{b}) \mathrm{FE}$ & $(\mathrm{B}) \mathrm{RE}$ & \\
\hline KOFECGLDF & -.0816768 & -.0183158 & -.063361 &. \\
\hline KOFECGLDJ & -.028744 & -.0954989 & .0667549 &. \\
\hline KOFSOGLDF & .1556081 & .4712145 & -.3156065 &. \\
\hline KOFSOGLDF & .0086815 & -.1297476 & .1384291 &. \\
\hline KOFPOGLDF & .0202137 & .0011669 & .0190468 &. \\
\hline KOFPOGLDF & -.0044234 & -.1006144 & .0961909 &. \\
\hline CHI-SQ & 153.71 & P-VALUE & 0.00000 & \\
\hline
\end{tabular}

Lastly, the same test applied on European union panels to keep the findings comparable. The results of Hausman tests are given below. 
Table 4.4: Hausman Test for Model Specification (EUROPEAN UNION)

\begin{tabular}{|l|l|l|l|l|}
\hline HAUSMAN FE & COEFFICIENTS & COEFFICIENTS & DIFFERENCE & S. E \\
& $(\mathrm{b}) \mathrm{FE}$ & $(\mathrm{b}) \mathrm{RE}$ & \\
\hline KOFECGLDF & .1967871 & .207065 & -.0102779 &. \\
\hline KOFECGLDJ & .3241203 & .3054774 & .0186429 &. \\
\hline KOFSOGLDF & .1283808 & .1220918 & .006289 &. \\
\hline KOFSOGLDJ & -.8093024 & -.7828075 & -.0264949 &. \\
\hline KOFPOGLDF & -.5440919 & -.5968833 & .0527914 &. \\
\hline KOFPOGLDJ & -.2521299 & -.2362241 & -.0159058 & .002536 \\
\hline CHI-SQ & 22155.96 & P-VALUE & 0.00 & \\
\hline
\end{tabular}

In the table 3.4, the results reveal the fixed effects model is better. In the next step, we apply modified Wald test to check heteroscedasticity. Moreover, we apply Wooldridge test to check autocorrelation of BRICS, NEXT11, EAGLE and EUROPEAN UNIONS in the model. The results are given in the below table:

Table 4.5: Heteroscedasticity and Autocorrelation Test

\begin{tabular}{|l|l|l|l|l|}
\hline Test name & $\begin{array}{l}\text { T statistics/ } \\
\text { P-value } \\
\text { BRICS }\end{array}$ & $\begin{array}{l}\text { T statistics/ } \\
\text { P-value } \\
\text { NEXT11 }\end{array}$ & $\begin{array}{l}\text { T statistics/ } \\
\text { P-value } \\
\text { EAGLE }\end{array}$ & $\begin{array}{l}\text { T statistics/ } \\
\text { P-value }\end{array}$ \\
EU
\end{tabular}

In table 3.5, modified Wald test is used to see heteroscedasticity in the model and the results show that chi- square test statistics presented in table are unable to reject our null hypothesis. Wooldridge test has applied to check the autocorrelation in the model and the results showed that chi-square statistics accept the null hypothesis.

To check multicollinearity among variables, VIF test has applied and the mean VIF shows that there is no multicollinearity among the variables. The results for BRICS panel are given below; 
Table 4.6: Variance Inflation Factor (BRICS)

\begin{tabular}{|l|l|l|}
\hline VARIABLES & VIF & 1 /VIF \\
\hline KOFEcGIdflog & 6.08 & 0.164500 \\
\hline KOFEcGIdJlog & 3.36 & 0.297668 \\
\hline KOFSOGIdflog & 31.24 & 0.032011 \\
\hline KOFSOGIdJlog & 9.15 & 0.109328 \\
\hline KOFPOGIdflog & 4.43 & 0.225754 \\
\hline KOFPOGIdJlog & 7.45 & 0.134155 \\
\hline MEAN VIF & 12.02 & \\
\hline
\end{tabular}

The table reveals that mean vif value is 12.02 that shows there is no multicollinearity in the variables of the model. To check multicollinearity among variables, VIF test has applied and the mean VIF proves nill multicollinearity among the variables. The results for EUROPEAN UNION panel are given below;

Table 4.7: Variance Inflation Factor (European Union)

\begin{tabular}{|l|l|l|}
\hline VARIABLES & VIF & 1 VIF \\
\hline KOFEcGIdflog & 2.93 & 0.341601 \\
\hline KOFEcGIdJlog & 2.00 & 0.931559 \\
\hline KOFSOGIdflog & 4.80 & 0.208452 \\
\hline KOFSOGIdJlog & 6.50 & 0.153809 \\
\hline KOFPOGIdflog & 2.15 & 0.464465 \\
\hline KOFPOGIdJlog & 2.37 & 0.422053 \\
\hline MEAN VIF & 8.24 & \\
\hline
\end{tabular}

The table reveals that mean vif value is 8.24 that shows there is no multicollinearity in the variables of the model. To check multicollinearity among variables, VIF test has applied and the mean VIF proves that nill multicollinearity among the variables. The results for Next11 panel are given below;

Table 4.8: Variance Inflation Factor (NEXT11)

\begin{tabular}{|l|l|l|}
\hline VARIABLES & VIF & $1 /$ VIF \\
\hline KOFEcGIdflog & 2.33 & 0.429866 \\
\hline KOFEcGIdJlog & 5.10 & 0.196055 \\
\hline
\end{tabular}




\begin{tabular}{|l|l|l|}
\hline KOFSOGIdflog & 12.35 & 0.080970 \\
\hline KOFSOGIdJlog & 10.85 & 0.092133 \\
\hline KOFPOGIdflog & 6.48 & 0.154396 \\
\hline KOFPOGIdJlog & 5.81 & 0.172212 \\
\hline MEAN VIF & 21.57 & \\
\hline
\end{tabular}

The table reveals that mean vif value is 21.57 that shows there is no multicollinearity in the variables of the model. To check multicollinearity among variables, VIF test has applied and the mean VIF shows that there is no multicollinearity among the variables. The results for Eagle panel are given below;

Table 4.9: Variance Inflation Factor (EAGLE)

\begin{tabular}{|l|l|l|}
\hline VARIABLES & VIF & $1 /$ VIF \\
\hline KOFEcGIdflog & 2.07 & 0.482315 \\
\hline KOFEcGIdJlog & 6.76 & 0.147874 \\
\hline KOFSOGIdflog & 13.77 & 0.072604 \\
\hline KOFSOGIdJlog & 10.82 & 0.092396 \\
\hline KOFPOGIdflog & 1.66 & 0.603560 \\
\hline KOFPOGIdJlog & 4.52 & 0.221483 \\
\hline MEAN VIF & 21.27 & \\
\hline
\end{tabular}

The table reveals that mean vif value is 21.27 that shows there is no multicollinearity in the variables of the model.

Empirical Resources

This chapter provides the results of the specified models for four above mentioned regional cooperation and also analyzes these results based on previous literature. Table 4.1 depicts the effects of defacto and dejure economic, political and social GLOB on CO2 emissions by taking the data of countries cooperated in EAGLE by three separate models.

Table 5.1: CO2 emissions and KOF GLOB index (EAGLE cooperation)

\begin{tabular}{|l|l|l|l|}
\hline Variables & \multicolumn{2}{|l|}{ Log of CO2 emmisions } \\
\hline & $(1)$ & $(2)$ & $(3)$ \\
\hline C & -5.516041 & -5.258690 & -5.0186 \\
\hline
\end{tabular}




\begin{tabular}{|c|c|c|c|}
\hline & $(0.0000)$ & $(0.0000)$ & $(0.0000)$ \\
\hline $\begin{array}{l}\text { Log of KOF defacto economic } \\
\text { Gloablization }\end{array}$ & $\begin{array}{l}0.016863 \\
(0.7277)\end{array}$ & & \\
\hline $\begin{array}{l}\text { Log of KOF dejure economic } \\
\text { Gloablization }\end{array}$ & $\begin{array}{l}0.17659^{*} \\
(0.0123)\end{array}$ & & \\
\hline $\begin{array}{l}\text { Log of KOF defacto Political } \\
\text { Gloablization }\end{array}$ & & $\begin{array}{l}-0.007655 \\
(0.9562)\end{array}$ & \\
\hline $\begin{array}{l}\text { Log of KOF dejure Political } \\
\text { Gloablization }\end{array}$ & & $\begin{array}{l}0.0061697 \\
(0.5960)\end{array}$ & \\
\hline $\begin{array}{l}\text { Log of KOF defacto Social } \\
\text { Gloablization }\end{array}$ & & & $\begin{array}{l}-0.084058 \\
(0.4341)\end{array}$ \\
\hline $\begin{array}{l}\text { Log of KOF dejure Social } \\
\text { Gloablization }\end{array}$ & & & $\begin{array}{l}0.181310 * \\
(0.0517)\end{array}$ \\
\hline $\begin{array}{l}\text { Log of Purchasing power } \\
\text { parity }\end{array}$ & $\begin{array}{l}0.2259 \\
(0.0101)\end{array}$ & $\begin{array}{l}0.247144 \\
(0.0292)\end{array}$ & $\begin{array}{l}0.147311 \\
(0.2039)\end{array}$ \\
\hline $\begin{array}{l}\text { Log of agedependancy } \\
\text { Ratio }\end{array}$ & & & \\
\hline Log of human capital index & $\begin{array}{l}0.36625 \\
(0.0026)\end{array}$ & $\begin{array}{l}0.369652 \\
(0.0071)\end{array}$ & $0.422775^{* * *}(0.0012)$ \\
\hline $\mathrm{R} 2$ & 0.5248 & 0.98128 & 0.9816 \\
\hline Selected model & Random effects & $\begin{array}{l}\text { Fixed } \\
\text { Effects }\end{array}$ & Fixed effects \\
\hline Included cross sections & 8 & 8 & 8 \\
\hline Included observations & 208 & 208 & 208 \\
\hline
\end{tabular}

In the above table, the results show that dejure economic and social GLOB has positive sign that show there is positive relationship with dependent variable. It reveals that dejure economic and social GLOB increases $\mathrm{CO} 2$ emissions while defacto GLOBs in all the three divisions have not significant impact on $\mathrm{CO} 2$ emissions. 
Moreover, the purchasing power parity and human capital have positive influence on $\mathrm{CO} 2$ emissions. This shows that economic social GLOB can create problems for the government of the countries. Moreover, the effect of economic GLOB on carbon dioxide is positive and significant. This proves that economic GLOB can affect quality of environment.

GLOB is a multi-dimensional concept and includes economic, political, and social dimensions. Moreover, trade liberalization, economic growth, investment, capital flows, and technological change are the key factors of economic GLOB (Torres 2001). Table 4.2 depicts the effects of defacto and dejure economic, political and social GLOB on CO2 emissions by taking the data of countries cooperated in NEXT11 by three separate models.

Table 5.2: CO2 emissions and KOF GLOB index (NEXT11 cooperation)

\begin{tabular}{|c|c|c|c|}
\hline Variables & Log of CO2 emmisi & & \\
\hline & (1) & (2) & (3) \\
\hline $\mathrm{C}$ & $\begin{array}{l}-10.65231 \\
(0.0000)\end{array}$ & $\begin{array}{l}- \\
10.520206 \\
(0.0000)\end{array}$ & $\begin{array}{l}-5.07703 \\
(0.0000)\end{array}$ \\
\hline $\begin{array}{l}\text { Log of KOF defacto } \\
\text { economic Gloablization }\end{array}$ & $0.1085863 *(0.020)$ & & \\
\hline $\begin{array}{l}\text { Log of KOF dejure economic } \\
\text { Gloablization }\end{array}$ & $\begin{array}{l}0.4507843 * \\
(0.0000)\end{array}$ & & \\
\hline $\begin{array}{l}\text { Log of KOF defacto Political } \\
\text { Gloablization }\end{array}$ & & $\begin{array}{l}.2361666^{*} \\
(0.052)\end{array}$ & \\
\hline $\begin{array}{l}\text { Log of KOF defacto Political } \\
\text { Gloablization }\end{array}$ & & $\begin{array}{c}0.2258446 \\
*(0.0000)\end{array}$ & \\
\hline $\begin{array}{l}\text { Log of KOF dejure Political } \\
\text { Gloablization }\end{array}$ & & $\begin{array}{l}0 . \\
0110265 \\
(0.837)\end{array}$ & \\
\hline $\begin{array}{l}\text { Log of KOF defacto Social } \\
\text { Gloablization }\end{array}$ & & & $-.2547978 *(0.002)$ \\
\hline $\begin{array}{l}\text { Log of KOF dejure Social } \\
\text { Gloablization }\end{array}$ & & & $\begin{array}{l}.1399637 \\
(0.183)\end{array}$ \\
\hline $\begin{array}{l}\text { Log of Purchsing power } \\
\text { parity }\end{array}$ & $\begin{array}{l}-.4897653 \\
(0.000)\end{array}$ & $\begin{array}{l}- \\
0.5170552 \\
(0.0000)\end{array}$ & $\begin{array}{l}-.4851763 * * * \\
(0.000)\end{array}$ \\
\hline Log of human capital index & .7962333 & 0.7906424 & $.7815804 * * *$ \\
\hline
\end{tabular}




\begin{tabular}{|l|l|c|l|}
\hline & $(0.000)$ & $(0.0000)$ & $(0.000)$ \\
\hline R2 & 0.2185 & 0.1663 & 0.1978 \\
\hline Selected model & Random Effects & $\begin{array}{c}\text { Random } \\
\text { Effects }\end{array}$ & Random effects \\
\hline Included cross sections & 28 & 28 & 28 \\
\hline Included observations & 696 & 700 & 696 \\
\hline
\end{tabular}

The Table 5.3 shows the results for eurpeon union, where dejure economic GLOB is good for environment but opposite for economic defacto GLOB. Whereas, defacto political globalization worsen the environment in this cooperation by increasing $\mathrm{CO} 2$ emissions. In addition, the defacto social GLOB has a negative and significant effect on $\mathrm{CO} 2$ emissions. In this case, the political system that fortifies GLOB and especially from producing energy is the main instrument of both transformations. Moreover, GLOB plays a practical role and making global level policies to reduce the severe impact of environmental threats (Najam et al. 2016).

Table 4.4 depicts the effects of defacto and dejure economic, political and social GLOB on CO2 emissions by taking the data of countries cooperated in BRICS by three separate models.

Table 5.4: CO2 emissions and KOF GLOB index (BRICS).

\begin{tabular}{|l|l|r|r|}
\hline Variables & \multicolumn{2}{l|}{ Log of CO2 emmisions } & $(2)$ \\
\hline & $(1)$ & -5.998611 & -5.19182 \\
\hline C & -5.094896 & $(0.0000)$ & $(0.000)$ \\
\hline $\begin{array}{l}\text { Log of KOF defacto economic } \\
\text { Gloablization }\end{array}$ & $-.0 .000)$ & & \\
\hline $\begin{array}{l}\text { Log of KOF dejure economic } \\
\text { Gloablization }\end{array}$ & $(0.100)$ & & \\
\hline $\begin{array}{l}\text { Log of KOF defacto Political } \\
\text { Gloablization }\end{array}$ & $(0.489)$ & & \\
\hline $\begin{array}{l}\text { Log of KOF dejure Political } \\
\text { Gloablization }\end{array}$ & & -1.554412 & \\
& & $*(0.000)$ & \\
\hline
\end{tabular}




\begin{tabular}{|l|l|l|l|}
\hline $\begin{array}{l}\text { Log of KOF defacto Social } \\
\text { Gloablization }\end{array}$ & & & -.0073153 \\
& & & $(0.955)$ \\
\hline $\begin{array}{l}\text { Log of KOF dejure Social } \\
\text { Gloablization }\end{array}$ & & & $(0.653)$ \\
\hline Log of Purchsing power parity & -.2107856 & 1.041403 & $-.2372302^{* * *}$ \\
\hline Log of human capital index & $(0.001)$ & $(0.0000)$ & $(0.001)$ \\
\hline R2 & .9305659 & -1.116325 & $.9792286^{* * *}(0.000)$ \\
\hline Selected model & $(0.000)$ & $(0.0000)$ & \\
\hline Included cross sections & 0.5131 & 0.8606 & 0.5312 \\
\hline Included observations & 128 & Random Effects & Fixed effects \\
\hline
\end{tabular}

These results showed that defacto economic GLOB has negative relationship with environmental degradation confirming the deteriorating impact of defacto economic GLOB on $\mathrm{CO} 2$ emissions. Whereas, in case of social GLOB, defacto index has negative effect on environment while dejure one also has negative influence on $\mathrm{CO} 2$ emissions. Moreover, in case of political GLOB dejure has negative relationship but defacto has positive impact on environmental degradation.

\section{Conclusion}

The study focused to find out the impact of defacto and dejure GLOB (as in explained in KOF GLOB index 2018) on Environmental degradation in EAGLE, BRICKS, EU \& NEXT11 countries. The defacto GLOB indicate the measures of GLOB include variables that represent flows and activities, de jure measures include variables that represent policies that, in principle, enable flows and activities. Whereas the environmental GLOB is measured by CO2 Emission.

The results show that dejure economic and social GLOB has significant impact on environmental degradation in EAGLE countries which indicates that the favorable trade \& financial GLOB policies in these countries enabled more economic GLOB led to more industrialization which deteriorates the environment in these countries. While Increased Social GLOB also increased the CO2 emissions in EAGLE countries. On the other hand, the political GLOB has no significant impact on Environmental degradation. In European Union far and less most countries have seen income inequality increasing year by year and due to increased social, political and economic GLOB he more production taken place, therefore more environmental degradation. Similar pattern I have observed in BRICKS and NEXT11 countries as well. As a result of limited convergence process and increasing inequality in all these regional coperations people are more unequal today than before.

During this study I have observed that though free trade and liberalization have expanded the canvas for free markets, but it could not break the panorama of developed and developing. In my view after conducting this study is 
that small size economies could not be benefitted more by regional cooperations as their big size economies's counter parts did. Maybe lifting all trade barriers did not support the small size economies and more defacto economic and social GLOB increased environmental degradation in these countries.

Governments should religiously follow the environmental laws in order to avoid the increasing environmental degradation. The superpowers in world should obey these rules at first. Recycling, less use of plastic and opposition of deforestation should be mandatory. The ethical codes of conducts in trade are no more effective in this rapidly globalized capitalistic world therefore the accountability and implication of law should be the priority of states and world trade institutions.

More capital and investment should be done in creating awareness about climate change and environmental degradation. All states, regional coperations, and international trade institutions should spend their resources for more research in this field so the world can find alternative sources of energies which could not harm the environment.

The speed of GLOB should not be so rapid that it decreases the quality of life even vanishing the life. The one case recently we have seen in the form of COVID 19. This showed us that ignoring environment could cost not only the growth \& development but large number of causalities.

\section{References}

Ahmed, K., Long, W. (2012), Environmental Kuznets curve and Pakistan: An empirical analysis. ProcediaEconomics and Finance, 1, 4-13.

Alam, M.J., Begum, I.A., Buysse, J., Huylenbroeck, G.V. (2012), Energy consumption, carbon emissions and economic growth nexus in Bangladesh: Cointegration and dynamic causality analysis. Energy Policy, 45, 217-225.

Baek, J. (2015), Environmental Kuznets curve for CO2 emissions: The case of Arctic countries. EnergyEconomics, 50, 13-17.

Baek, J., Kim, H.S. (2013), Is economic growth good or bad for the environment? Empirical

evidence fromKorea. Energy Economics, 36, 744-749.

Balaguer, J., Cantavella, M. (2016), Estimating the environmental Kuznets curve for Spain by consideringfuel oil prices (1874-2011). Ecological Indicators, 60, 853-859.

Balsalobre-Lorente, D., Driha, O. M., Shahbaz, M., \& Sinha, A. (2020). The effects of tourism and globalization over environmental degradation in developed countries. Environmental Science and Pollution Research, 27(7), 7130-7144.

Cho, C.H., Chu, Y.P., Yang, H.Y. (2014), An environment Kuznets curve for GHG emissions: A panelcointegration analysis. Energy Sources, Part B: Economics, Planning, and Policy, 9(2), 120-129.

Cole, M.A. (2004), Trade, the pollution haven hypothesis and the environmental Kuznets curve:

Examiningthe linkages. Ecological Economics, 48(1), 71-81.

Cole, M.A., Rayner, A.J., Bates, J.M. (1997), The environmental Kuznets curve: An empirical analysis. Environment and Development Economics, 2(4), 401-416.

Dar, J.A., Asif, M. (2018), Does financial development improve environmental quality in Turkey? An application of endogenous structural breaks based cointegration approach. Management of EnvironmentalQuality: An International Journal, 29(2), 368-384. 
Dinda, S. (2004), Environmental Kuznets curve hypothesis: A survey. Ecological Economics, 49(4), 431-455.

Frankel JA (2009) Environmental effects of international trade. HKS Faculty Research Working

Paper Series RWP09-006, John F. Kennedy School of Government, Harvard University. http://nrs. harvard.edu/urn 3: HUL.InstRepos:4481652

Ghosh, S. (2010), Examining carbon emissions-economic growth nexus for India: A multivariate cointegration approach. Energy Policy, 38(6), 3008-3014.

Grossman GM, Krueger AB (1991) Environmental impacts of a north American free trade agreement.National bureau of economic research working paper 3914, NBER, Cambridge, MA

Grossman, G., Krueger, A. (1991), Environmental Impacts of a North American Free Trade Agreement, National Bureau of Economics Research Working Paper, No. 3194. Cambridge: NBER.

Javid, M., Sharif, F. (2016), Environmental Kuznets curve and financial development in Pakistan. Renewable and Sustainable Energy Reviews, 54, 406-414.

Jayanthakumaran, K., Verma, R., Liu, Y. (2012), CO2 emissions, energy consumption, trade and income:A comparative analysis of China and India. Energy Policy, 42, 450-460.

Kijima M, Nishide K, Ohyama A (2010) Economic models for the environmental Kuznets curve: a survey.J Econ Dyn Control 34(7): 1187-1201

Mallick, L., Tandi, S.M. (2015), Energy consumption, economic growth, and CO2 emissions in SAARCcountries: Does environmental Kuznets curve exist? The Empirical Econometrics and Quantitative Economics Letters, 4, 57-69.

María, P.P., Jesús, J.D. (2016), Economic growth and energy consumption: The energy-

environmentalKuznets curve for Latin America and the Caribbean. Renewable and Sustainable Energy Reviews, 60,1343-1350.

Najam A, Runnalls D, Halle M (2016) Environment and GLOB: five propositions 2010. The GLOB and Environment Reader, 94. https://www.wiley.com

Nasir, M., Rehman, F.U. (2011), Environmental Kuznets curve for carbon emissions in Pakistan: Anempirical investigation. Energy Policy, 39(3), 1857-1864.

Omri, A., Daly, S., Rault, C., Chaibi, A. (2015), Financial development, environmental quality, trade andeconomic growth: What cause what in MENA countries. Energy Economics, 48, 242-252.

Onifade, S. T., Gyamfi, B. A., Haouas, I., \& Bekun, F. V. (2021). Re-examining the roles of economic globalization and natural resources consequences on environmental degradation in E7 economies: Are human capital and urbanization essential components? Resources Policy, 74, 102435.

Ozatac, N., Gokmenoglu, K.K., Taspinar, N. (2017), Testing the EKC hypothesis by considering tradeopenness, urbanization, and financial development: The case of Turkey. Environmental Science and Pollution Research, 24(20), 16690-16701. 
Pao, H.T., Tsai, C.M. (2011), Multivariate granger causality between CO2 emissions, energy

consumption,FDI (foreign direct investment) and GDP (gross domestic product): Evidence from a panel of BRIC (Brazil, Russia Federation, India, and China) countries. Energy, 36(1), 685693.

Phong, L.H., Van, D.T.B., Bao, H.H.G. (2020), The role of GLOB on carbon dioxide emission in Vietnam incorporating industrialization, urbanization, gross domestic product per capita and energy use. International Journal of Energy Economics and Policy, 8(6), 275-283.

Rehman, M.U., Rashid, M. (2017), Energy consumption to environmental degradation, the growth appetitein SAARC nations. Renewable Energy, 111, 284-294.

Roca, J., Padilla, E., Farre, M., Galletto, C. (2001), Economic growth and atmospheric pollution in Spain:Discussing the environmental Kuznets curve hypothesis. Ecological Economics, 39(1), 85-99.

Shahbaz M, Khan S, Ali A, Bhattacharya M (2017a) The impact of Globalization on CO2

emissions inChina. Singap Econ Rev 62(04):929-957

Sharif, A., Godil, D. I., Xu, B., Sinha, A., Khan, S. A. R., \& Jermsittiparsert, K. (2020). Revisiting the role of tourism and globalization in environmental degradation in China: Fresh insights from the quantile ARDL approach. Journal of Cleaner Production, 272, 122906.

Sinha, A., Sen, S. (2016), Atmospheric consequences of trade and human development: A case of BRICcountries. Atmospheric Pollution Research, 7(6), 980-989.

Suki, N. M., Sharif, A., Afshan, S., \& Suki, N. M. (2020). Revisiting the Environmental Kuznets Curve in Malaysia: The role of globalization in sustainable environment. Journal of Cleaner Production, 264, 121669.

Wang, Y., Kang, L., Wu, X., Xiao, Y. (2013), Estimating the environmental Kuznets curve for ecological footprint at the global level: A spatial econometric approach. Ecological Indicators, 34, 15-21.

Zaman, K., Shahbaz, M., Loganathan, N., Raza, S.A. (2016), Tourism development, energy

consumptionand environmental Kuznets curve: Trivariate analysis in the panel of developed and developing countries. Tourism Management, 54, 275-283.

Zhang, S., Liu, X., Bae, J. (2017), Does trade openness affect CO2 emissions: Evidence from ten newly industrialized countries? Environmental Science and Pollution Research, 24(21), 17616-17625. 